\title{
Combined effect of active coating and modified atmosphere packaging on prolonging the shelf life of low-moisture Mozzarella cheese
}

\author{
Marianna Mastromatteo, ${ }^{*}$ Amalia Conte, ${ }^{*}$ Michele Faccia, $\dagger$ Matteo Alessandro Del Nobile, ${ }^{* 1}$ \\ and Angelo Vittorio Zambrinił \\ *Department of Agriculture, Food and Environment Science, University of Foggia, Via Napoli, 25 - 71122 Foggia, Italy \\ †Department of Soil, Plant and Food Science, University of Bari, Via Amendola, 165/A - 70126 Bari, Italy \\ fDepartment of Quality, Innovation, Safety, Environment, Granarolo S.p.A., Via Cadriano, 27/2 - 40127 Bologna, Italy
}

\begin{abstract}
In this work, the effect of active coating on the shelf life of low-moisture Mozzarella cheese packaged in air and modified atmosphere (MAP) was studied. The active coating was based on sodium alginate $(2 \%, \mathrm{wt} / \mathrm{vol})$ and potassium sorbate $(1 \%$, wt/vol). The MAP was made up of $75 \% \mathrm{CO}_{2}$ and $25 \% \mathrm{~N}_{2}$ (MAP1), $25 \% \mathrm{CO}_{2}$ and $75 \% \mathrm{~N}_{2}$ (MAP2), or $50 \% \mathrm{CO}_{2}$ and $50 \% \mathrm{~N}_{2}$ (MAP3). The product quality decay was assessed by monitoring microbiological and sensory changes during storage at 4,8 , and $14^{\circ} \mathrm{C}$. Results showed that the combination of active coating and MAP was able to improve the preservation of low-moisture Mozzarella cheese. Specifically, the shelf life increased up to $160 \mathrm{~d}$ for samples stored at $4^{\circ} \mathrm{C}$, and 40 and $11 \mathrm{~d}$ for those at 8 and $14^{\circ} \mathrm{C}$, respectively. A faster quality decay for untreated samples packaged in air was observed. In particular, the Pseudomonas spp. growth and the appearance of molds were responsible for product unacceptability. The combination of active coating and MAP represents a strategic solution to prolong the shelf life of lowmoisture Mozzarella cheese and to ensure the safety of the product under thermal abuse conditions.
\end{abstract}

Key words: low-moisture Mozzarella cheese, active coating, modified atmosphere packaging, shelf life

\section{INTRODUCTION}

Mozzarella cheese is one of several pasta filata cheeses originating in Italy. Two main types of Mozzarella are produced, based on moisture content (US FDA, 1989). In particular, low-moisture (LM) Mozzarella cheese (moisture content: $45-54 \%$ ) is often used for pizza toppings or as an ingredient in other foods, whereas highmoisture Mozzarella cheese (moisture content: 56-65\%), which is the principal Italian Mozzarella exported, is usually consumed fresh as a table cheese (Gammariello

Received May 6, 2013.

Accepted September 26, 2013.

${ }^{1}$ Corresponding author: ma.delnobile@unifg.it et al., 2008; Conte et al., 2009; Del Nobile et al., 2009). Generally, LM Mozzarella cheese is packaged under vacuum in trays of polypropylene sealed with a plastic top film and stored at $8^{\circ} \mathrm{C}$. In these conditions, the shelf life is less than $5 \mathrm{wk}$; as the product firmness increases, the odor becomes unpleasant and the cheese develops a bitter taste.

Extending the shelf life of Mozzarella cheese is an important issue to the dairy industry, due to the high interest in extending the distribution of traditional products beyond market borders. The main ways of improving the food product quality and shelf life are based on using high-quality raw materials, developing process innovations, and adopting suitable storage conditions (Farkye et al., 1991; Kindstedt, 1993; Brody, 2001; Conte et al., 2009).

Edible films and coatings prepared from polysaccharides, proteins, and lipids have a variety of advantages, such as biodegradability, edibility, biocompatibility, aesthetic appearance, and barrier properties, against oxygen and physical stress. Edible films prepared from hydrocolloids, such as sodium alginate, form strong films and exhibit poor water resistance because of their hydrophilic nature (Guilbert, 1986).

The use of edible coatings for a wide range of food products has received increased interest, because coatings can serve as a carrier for a wide range of food additives, including antibrowning agents, colorants, flavors, nutrients, spices, and various antimicrobials that can extend product shelf life and reduce the risk of pathogen growth on the food surface (Cagri et al., 2004; Pranoto et al., 2005; Conte et al., 2009; Del Nobile et al., 2009).

The potential of modified atmosphere packaging (MAP) and active packaging to extend the shelf life of different dairy products has been demonstrated (Floros et al., 2000; Pantaleão et al., 2007; Papaioannou et al., 2007). Modified atmosphere packaging reduces physiological changes, respiration rates, oxidation reactions, and microbial growth by changing the level of gases that surround the product. To the best of our knowledge, very few papers have discussed Mozzarella 
cheese packaged in MAP. Eliot et al. (1998) reported that shredded Mozzarella cheese packaged in MAP containing levels of $75 \% \mathrm{CO}_{2}$ was well protected from undesirable organism and gas formation. Alves et al. (1996) also found that microbial growth in sliced Mozzarella cheese packaged in MAP was delayed with high concentrations of $\mathrm{CO}_{2}$.

Considering the above, the aim of the current work was to evaluate how the combination of active coating and MAP can improve the shelf life of LM Mozzarella cheese. Specifically, the quality decay was assessed by monitoring the microbiological and sensorial subindices of the product and the effect of temperature was also investigated.

\section{MATERIALS AND METHODS}

\section{Active Coating and Packaging of LM Mozzarella Cheese}

Low-moisture Mozzarella cheese samples ( 150-200 g) were kindly provided by a local cheese factory (Capurso Azienda Casearia SpA, Gioia del Colle, Bari, Italy) and brought to our laboratory in boxes containing 10 pieces each under refrigeration $\left(4^{\circ} \mathrm{C}\right)$. According to information supplied by the manufacturer, all cheeses were produced by a common-milled curd procedure using starter culture that consisted exclusively of Streptococcus thermophilus, and with fermentation-produced chymosin as coagulant. Samples were removed from their packages and subjected to the active coating treatment. In particular, samples were dipped into a sodium alginate solution prepared by dissolving sodium alginic acid powder $(2 \%$, wt/vol $)$ and potassium sorbate $(1 \%, \mathrm{wt} / \mathrm{vol})$ in sterile distilled water tempered to $50^{\circ} \mathrm{C}$. Then, the coated samples were immersed into a crosslinking solution of calcium chloride $(5 \%$, wt/vol) for $1 \mathrm{~min}$ to promote the alginate gel-forming process. After treatment, the coated LM Mozzarella cheese samples (COAT) were air dried for $2 \mathrm{~min}$. Then, 2 pieces per package were placed in commercially available bags (nylon/polyethylene) with a thickness of 95 $\mu \mathrm{m}$ (Valco S.r.l., Bergamo, Italy). The bags were 170 $\times 250 \mathrm{~mm}$ long, with an oxygen transmission rate of $49.39 \mathrm{~cm}^{3} /\left(\mathrm{m}^{2} \cdot \mathrm{d}\right)$, carbon dioxide transmission rate of $162.83 \mathrm{~cm}^{3} /\left(\mathrm{m}^{2} \cdot \mathrm{d}\right)$, and water vapor transmission rate of $1.64 \mathrm{~g} /\left(\mathrm{m}^{2} \cdot \mathrm{d}\right)$. In addition, LM Mozzarella cheese samples without active coating were used as control (CTRL). All samples were sealed in air and under modified atmosphere conditions. The gas combinations used were the following: MAP1: $75 \% \mathrm{CO}_{2}$ and $25 \%$ $\mathrm{N}_{2}$, MAP2: $25 \% \mathrm{CO}_{2}$ and $75 \% \mathrm{~N}_{2}$, and MAP3: $50 \%$ $\mathrm{CO}_{2}$ and $50 \% \mathrm{~N}_{2}$. All samples were stored at 4, 8, and $14^{\circ} \mathrm{C}$. The sodium alginic acid, potassium sorbate, and calcium chloride were from Farmalabor S.r.l. (Canosa di Puglia, Italy).

\section{Microbiological Analyses}

Microbiological analyses for total viable count (TVC), Pseudomonas spp., Enterobacteriaceae, lactic acid bacteria (LAB), and lactococci were performed according to the International Organization for Standardization (ISO, 2001; ISO 8261:2001). Media and conditions used for the enumerations were as follows: plate count agar (Oxoid SpA, Milan, Italy) incubated at $30^{\circ} \mathrm{C}$ for 24 to $48 \mathrm{~h}$ for TVC; Pseudomonas agar base (Oxoid SpA) with $10 \mathrm{mg}$ of cetrimide/L, $10 \mathrm{mg}$ of fucidine/L, and $50 \mathrm{mg}$ of cephaloridine/L selective supplement (Oxoid SpA), incubated at $25^{\circ} \mathrm{C}$ for $48 \mathrm{~h}$ for Pseudomonas spp. count; for Enterobacteriaceae, violet red bile glucose agar (Oxoid SpA) incubated at $37^{\circ} \mathrm{C}$ for 18 to $24 \mathrm{~h}$; de Man, Rogosa, and Sharpe (MRS) agar (Oxoid SpA) incubated anaerobically in HP 11 jars (Oxoid SpA) at $37^{\circ} \mathrm{C}$ for 2 to $4 \mathrm{~d}$ for LAB; and M17 agar (Oxoid SpA) incubated anaerobically in HP 11 jars (Oxoid SpA) at $37^{\circ} \mathrm{C}$ for $48 \mathrm{~h}$ for lactococci. The microbiological analyses were carried out twice on 2 different batches.

To determine the effectiveness of the packaging strategy, the microbiological acceptability limit (MAL), defined as the storage time at which microbial counts of the selected spoilage group reached the threshold value permitted, was calculated as reported by Del Nobile et al. (2009). The microbiological limit was fixed at $10^{6}$ cfu/g for Pseudomonas spp. (Conte et al., 2009).

\section{Sensory Analysis}

Low-moisture Mozzarella samples were subjected to sensory analysis by a panel consisting of 7 trained evaluators. The panel was selected and trained according to the International Organization for Standardization method 8586-1993 (ISO, 1993). The selection was made considering various aspects: interest and motivation, eating habits (consumption of dairy products), ability to communicate sensations, time available for analysis sessions, ability to concentrate, and performance training. Eight sessions of $1 \mathrm{~h}$ each were required to define the sensory profile and to familiarize the testers with the characteristics of LM Mozzarella cheese. After training, panelists were asked to evaluate color, odor, taste, and firmness attributes of LM Mozzarella cheese. Low-moisture Mozzarella samples were presented to panelists with and without active coating and they were asked to describe differences between samples using a scale from 1 to 7 (Corradini and Innocente, 2002). Panelists were asked to base their decision on 
the sample overall quality, only taking into account color, odor, taste, and firmness. Therefore, the samples' overall quality has to be considered as an average of the above-mentioned sensory attributes (i.e., color, odor, taste, and firmness), as weighted by the panelist (Conte et al., 2009). A score of 4 was the minimum threshold value for cheese acceptability. The sensorial acceptability limit (SAL; i.e., the storage time at which the sensory attribute reaches the threshold) was calculated as reported by Conte et al. (2009). During the panel test, the panelists were also asked to search for presence of visual molds and the visual molds time (VMT) was determined. The VMT is defined as the average time between the latest storage time at which molds were not visible and the earliest storage time at which molds were visible. The sensory evaluation of samples was stopped as soon as visible molds were detected on product surface.

\section{Shelf-Life Calculation}

The overall quality of a given product is related to the several quality subindices. Therefore, the shelf life of a packed product is, by definition, the time at which one of the product quality subindices reaches its threshold value. In this work, the shelf life of each tested sample was calculated as the lowest value among $\mathrm{MAL}^{\text {Pseudomonas }}, \mathrm{VMT}$, and the SAL in terms of overall quality $\left(\mathbf{S A L}^{\mathrm{OQ}}\right)$.

\section{Statistical Analysis}

Experimental data of all tested samples were compared by one-way ANOVA. A Duncan's multiple range test, with the option of homogeneous groups $(P<0.05)$, was used to determine significant differences among treatments. To this aim, Statistica 7.1 for Windows software (StatSoft Inc., Tulsa, OK) was used.

\section{RESULTS AND DISCUSSION}

\section{LM Mozzarella Cheese Stored at $4^{\circ} \mathrm{C}$}

Microbiological Analyses. Cheese microflora is dominated by LAB introduced with a cheese starter. The remaining microorganisms include thermoresistant bacteria originating from the raw material remaining after pasteurization of milk and microflora consisting of postpasteurization contamination (Molska, 1988).

The microbial counts of microorganisms investigated in this study are reported in Table 1. Microbial counts were monitored until the packaged LM Mozzarella cheese reached either its microbiological or sensorial threshold value or until visible molds appeared on its surface. The observed changes of TVC depended on the type of packaging strategy used. A slight reduction in the TVC was observed for samples packaged in the atmosphere having high $\mathrm{CO}_{2}$ concentration, with respect to the samples packaged in air and with low $\mathrm{CO}_{2}$ levels. Specifically, TVC showed an initial cell load of about $4.3 \mathrm{log} \mathrm{cfu} / \mathrm{g}$ and no significant differences between samples were observed up to $9 \mathrm{~d}$. At $28 \mathrm{~d}$ of storage, control samples packaged with high $\mathrm{CO}_{2}$ concentration (CTRL-MAP1 and CTRL-MAP3) showed a lower cell load $(\sim 4 \log \mathrm{cfu} / \mathrm{g})$ compared with samples in air (CTRL-air, $4.5 \log \mathrm{cfu} / \mathrm{g}$ ) and MAP with low $\mathrm{CO}_{2}$ concentration (CTRL-MAP2, 5.0 log cfu/g). A similar effect for the coated samples was also observed. This was probably due to the specific effect of $\mathrm{CO}_{2}$ on TVC, as confirmed in previous studies (Eliot et al., 1998). At $50 \mathrm{~d}$ of storage, the control MAP1 samples showed the lowest cell load, whereas the highest value was observed for COAT-MAP3 samples ( 6.0 log cfu/g). Then, the TVC progressively increased in all the cheese samples. The microbiological analyses for the control samples were interrupted at $78 \mathrm{~d}$, as the samples were unacceptable from the sensory point of view, whereas for the coated samples, the TVC increased up to a value of about $7.0 \mathrm{log} \mathrm{cfu} / \mathrm{g}$ at the end of storage. The analyses for coated samples in air and under low $\mathrm{CO}_{2}$ levels (COAT-air and COAT-MAP2) were stopped at a shorter storage time than the other coated samples, due to unacceptable sensory characteristics.

Lactic acid bacteria counts varied little and significant differences between samples were observed only after $28 \mathrm{~d}$ of storage. In particular, control samples presented a lower cell load than the coated samples. Moreover, at $78 \mathrm{~d}$ of storage the cell load of LAB reached a value of about $5.0 \mathrm{log} \mathrm{cfu} / \mathrm{g}$ for control samples and 6.0 $\log \mathrm{cfu} / \mathrm{g}$ for coated samples. Probably, the diffusion of the headspace oxygen to the surface of product was slowed down by the oxygen resistance of the coating. Therefore, oxygen sensitivity of anaerobic LAB would explain the lower cell load observed for the uncoated samples. The concentration of LAB increased up to a cell load of $7.0 \mathrm{log} \mathrm{cfu} / \mathrm{g}$ at the end of storage.

For lactococci, significant differences at 5, 16, and 78 $\mathrm{d}$ of storage were observed. In particular, at $5 \mathrm{~d}$ of storage, CTRL-MAP3 samples (6.8 log cfu/g) were significantly different from CTRL-air and COAT-air samples $(7.2 \mathrm{cfu} / \mathrm{g})$. At $16 \mathrm{~d}$ of storage, the lowest cell load for coated and uncoated samples under low $\mathrm{CO}_{2}$ levels (COAT-MAP2 and CTRL-MAP2) and coated samples under air ( 7.0 log cfu/g) was observed compared with the COAT-MAP3 samples (7.4 log $\mathrm{cfu} / \mathrm{g})$. Then, the microbial counts did not show significant differences until the end of storage and a cell load of about $7.0 \mathrm{log}$ $\mathrm{cfu} / \mathrm{g}$ for all samples was assessed. 
Table 1. Microbial counts of microorganisms for low-moisture Mozzarella cheese stored at $4^{\circ} \mathrm{C}$

Cell load $(\log \mathrm{cfu} / \mathrm{g})$

\begin{tabular}{|c|c|c|c|c|c|c|c|c|c|c|c|}
\hline \multirow[b]{2}{*}{ Microorganism } & \multirow[b]{2}{*}{ Sample $^{1}$} & \\
\hline & & d 0 & d 5 & d 9 & d 16 & d 28 & d 50 & d 78 & d 98 & d 145 & d 249 \\
\hline \multirow[t]{8}{*}{ Total viable count } & CTRL-air & $4.29 \pm 0.20^{\mathrm{a}}$ & $4.15 \pm 0.21^{\mathrm{a}}$ & $4.24 \pm 0.30^{\mathrm{a}}$ & $4.54 \pm 0.18^{\mathrm{ab}}$ & $4.50 \pm 0.28^{\mathrm{b}}$ & $4.76 \pm 0.20^{\mathrm{a}, \mathrm{b}}$ & $6.18 \pm 0.04^{\mathrm{a}}$ & - & - & - \\
\hline & CTRL-MAP1 & $4.29 \pm 0.20^{\mathrm{a}}$ & $4.24 \pm 0.34^{\mathrm{a}}$ & $4.44 \pm 0.23^{\mathrm{a}}$ & $4.41 \pm 0.15^{\mathrm{ab}}$ & $3.89 \pm 0.16^{\mathrm{a}}$ & $4.26 \pm 0.17^{\mathrm{a}}$ & $6.02 \pm 0.09^{\mathrm{a}}$ & - & - & - \\
\hline & CTRL-MAP2 & $4.29 \pm 0.20^{\mathrm{a}}$ & $4.21 \pm 0.29^{\mathrm{a}}$ & $4.54 \pm 0.23^{\mathrm{a}}$ & $4.19 \pm 0.41^{\mathrm{a}}$ & $5.17 \pm 0.18^{\mathrm{cd}}$ & $5.29 \pm 0.08^{\mathrm{ab}}$ & $5.61 \pm 0.22^{\mathrm{a}}$ & - & - & - \\
\hline & CTRL-MAP3 & $4.29 \pm 0.20^{\mathrm{a}}$ & $4.25 \pm 0.35^{\mathrm{a}}$ & $4.43 \pm 0.09^{\mathrm{a}}$ & $4.38 \pm 0.03^{\mathrm{ab}}$ & $3.92 \pm 0.32^{\mathrm{a}}$ & $4.83 \pm 0.10^{\mathrm{ab}}$ & $6.09 \pm 0.33^{\mathrm{a}}$ & - & - & - \\
\hline & COAT-air & $4.29 \pm 0.20^{\mathrm{a}}$ & $4.69 \pm 0.20^{\mathrm{a}}$ & $4.34 \pm 0.23^{\mathrm{a}}$ & $4.45 \pm 0.10^{\mathrm{ab}}$ & $5.40 \pm 0.32^{\mathrm{d}}$ & $5.23 \pm 0.26^{\mathrm{ab}}$ & $6.50 \pm 0.14^{\mathrm{a}}$ & $6.63 \pm 0.11^{\mathrm{ab}}$ & $6.60 \pm 0.15^{\mathrm{b}}$ & - \\
\hline & COAT-MAP1 & $4.29 \pm 0.20^{\mathrm{a}}$ & $4.25 \pm 0.36^{\mathrm{a}}$ & $4.44 \pm 0.17^{\mathrm{a}}$ & $4.63 \pm 0.07^{\mathrm{b}}$ & $4.34 \pm 0.37^{\mathrm{ab}}$ & $5.20 \pm 1.64^{\mathrm{ab}}$ & $6.52 \pm 0.11^{\mathrm{a}}$ & $6.30 \pm 0.18^{\mathrm{a}}$ & $6.88 \pm 0.12^{\mathrm{a}}$ & $7.10 \pm 0.14^{\mathrm{a}}$ \\
\hline & COAT-MAP2 & $4.29 \pm 0.20^{\mathrm{a}}$ & $4.31 \pm 0.43^{\mathrm{a}}$ & $4.58 \pm 0.24^{\mathrm{a}}$ & $4.41 \pm 0.13^{\mathrm{ab}}$ & $5.15 \pm 0.15^{\mathrm{cd}}$ & $5.06 \pm 1.22^{\mathrm{ab}}$ & $6.42 \pm 0.60^{\mathrm{a}}$ & $6.93 \pm 0.11^{\mathrm{b}}$ & $6.85 \pm 0.06^{\mathrm{a}}$ & - \\
\hline & COAT-MAP3 & $4.29 \pm 0.20^{\mathrm{a}}$ & $4.31 \pm 0.43^{\mathrm{a}}$ & $4.65 \pm 0.12^{\mathrm{a}}$ & $4.33 \pm 0.35^{\mathrm{ab}}$ & $4.74 \pm 0.30^{\mathrm{bc}}$ & $6.14 \pm 0.25^{\mathrm{b}}$ & $5.98 \pm 1.73^{\mathrm{a}}$ & $6.55 \pm 0.33^{\mathrm{ab}}$ & $6.89 \pm 0.14^{\mathrm{a}}$ & $7.26 \pm 0.20^{\mathrm{a}}$ \\
\hline \multirow[t]{8}{*}{ Lactic acid bacteria } & CTRL-air & $3.78 \pm 0.02^{\mathrm{a}}$ & $3.47 \pm 0.05^{\mathrm{a}}$ & $3.61 \pm 0.72^{\mathrm{a}}$ & $3.49 \pm 0.34^{\mathrm{a}}$ & $3.99 \pm 0.12^{\mathrm{bc}}$ & $4.72 \pm 0.26^{\mathrm{bc}}$ & $5.03 \pm 0.19^{\mathrm{ab}}$ & - & $0.00+$ & -1.00 \\
\hline & CTRL-MAP1 & $3.78 \pm 0.02^{\mathrm{a}}$ & $3.41 \pm 0.13^{\mathrm{a}}$ & $3.52 \pm 0.15^{\mathrm{a}}$ & $3.37 \pm 0.10^{\mathrm{a}}$ & $3.36 \pm 0.03^{\mathrm{ab}}$ & $3.76 \pm 0.06^{\mathrm{a}}$ & $5.22 \pm 0.23^{\mathrm{b}}$ & - & - & - \\
\hline & CTRL-MAP2 & $3.78 \pm 0.02^{\mathrm{a}}$ & $3.52 \pm 0.26^{\mathrm{a}}$ & $3.23 \pm 0.12^{\mathrm{a}}$ & $3.44 \pm 0.29^{\mathrm{a}}$ & $3.22 \pm 0.25^{\mathrm{a}}$ & $3.52 \pm 0.02^{\mathrm{a}}$ & $4.82 \pm 0.13^{\mathrm{ab}}$ & - & - & - \\
\hline & CTRL-MAP3 & $3.78 \pm 0.02^{\mathrm{a}}$ & $3.75 \pm 1.06^{\mathrm{a}}$ & $3.31 \pm 0.01^{\mathrm{a}}$ & $3.26 \pm 0.00^{\mathrm{a}}$ & $3.39 \pm 0.55^{\mathrm{ab}}$ & $4.37 \pm 0.19^{\mathrm{abc}}$ & $4.68 \pm 0.60^{\mathrm{a}}$ & - & - & - \\
\hline & COAT-air & $3.78 \pm 0.02^{\mathrm{a}}$ & $3.51 \pm 0.24^{\mathrm{a}}$ & $3.35 \pm 0.44^{\mathrm{a}}$ & $3.64 \pm 0.37^{\mathrm{a}}$ & $4.45 \pm 0.39^{\mathrm{c}}$ & $4.79 \pm 0.41^{\mathrm{bc}}$ & $6.01 \pm 0.14^{\mathrm{c}}$ & $6.23 \pm 0.04^{\mathrm{a}}$ & $6.35 \pm 0.01^{\mathrm{a}}$ & - \\
\hline & COAT-MAP1 & $3.78 \pm 0.02^{\mathrm{a}}$ & $3.22 \pm 0.37^{\mathrm{a}}$ & $3.40 \pm 0.28^{\mathrm{a}}$ & $3.48 \pm 0.20^{\mathrm{a}}$ & $3.50 \pm 0.28^{\mathrm{ab}}$ & $4.98 \pm 1.14^{\mathrm{c}}$ & $6.25 \pm 0.36^{\mathrm{c}}$ & $6.40 \pm 0.46^{\mathrm{ab}}$ & $7.11 \pm 0.30^{\mathrm{b}}$ & $7.13 \pm 0.18^{\mathrm{a}}$ \\
\hline & COAT-MAP2 & $3.78 \pm 0.02^{\mathrm{a}}$ & $3.30 \pm 0.06^{\mathrm{a}}$ & $3.15 \pm 0.21^{\mathrm{a}}$ & $3.43 \pm 0.07^{\mathrm{a}}$ & $4.21 \pm 0.23^{\mathrm{c}}$ & $4.04 \pm 0.19^{\mathrm{ab}}$ & $6.04 \pm 0.06^{\mathrm{c}}$ & $6.82 \pm 0.15^{\mathrm{b}}$ & $7.10 \pm 0.02^{\mathrm{b}}$ & - \\
\hline & COAT-MAP3 & $3.78 \pm 0.02^{\mathrm{a}}$ & $3.28 \pm 0.03^{\mathrm{a}}$ & $3.21 \pm 0.13^{\mathrm{a}}$ & $3.37 \pm 0.10^{\mathrm{a}}$ & $4.52 \pm 0.54^{\mathrm{c}}$ & $5.13 \pm 0.46^{\mathrm{c}}$ & $6.05 \pm 0.21^{\mathrm{c}}$ & $6.20 \pm 0.17^{\mathrm{a}}$ & $6.87 \pm 0.08^{\mathrm{b}}$ & $7.35 \pm 0.21^{\mathrm{a}}$ \\
\hline \multirow[t]{8}{*}{ Lactococci } & CTRL-air & $5.32 \pm 0.03^{\mathrm{a}}$ & $7.23 \pm 0.18^{\mathrm{b}}$ & $7.10 \pm 0.20^{\mathrm{a}}$ & $7.10 \pm 0.20^{\mathrm{ab}}$ & $7.15 \pm 0.10^{\mathrm{a}}$ & $6.57 \pm 0.41^{\mathrm{a}}$ & $6.63 \pm 0.32^{\mathrm{a}}$ & - & - & - \\
\hline & CTRL-MAP1 & $5.32 \pm 0.03^{\mathrm{a}}$ & $7.01 \pm 0.04^{\mathrm{ab}}$ & $7.34 \pm 0.26^{\mathrm{a}}$ & $7.29 \pm 0.24^{\mathrm{ab}}$ & $7.11 \pm 0.05^{\mathrm{a}}$ & $6.76 \pm 0.14^{\mathrm{a}}$ & $6.81 \pm 0.07^{\mathrm{ab}}$ & - & - & - \\
\hline & CTRL-MAP2 & $5.32 \pm 0.03^{\mathrm{a}}$ & $7.01 \pm 0.32^{\mathrm{ab}}$ & $7.26 \pm 0.05^{\mathrm{a}}$ & $7.06 \pm 0.06^{\mathrm{a}}$ & $7.25 \pm 0.30^{\mathrm{a}}$ & $6.67 \pm 0.16^{\mathrm{a}}$ & $6.97 \pm 0.12^{\mathrm{b}}$ & - & - & - \\
\hline & CTRL-MAP3 & $5.32 \pm 0.03^{\mathrm{a}}$ & $6.83 \pm 0.21^{\mathrm{a}}$ & $7.12 \pm 0.22^{\mathrm{a}}$ & $7.11 \pm 0.19^{\mathrm{ab}}$ & $7.02 \pm 0.45^{\mathrm{a}}$ & $6.62 \pm 0.14^{\mathrm{a}}$ & $7.05 \pm 0.21^{\mathrm{b}}$ & - & - & - \\
\hline & COAT-air & $5.32 \pm 0.03^{\mathrm{a}}$ & $7.20 \pm 0.18^{\mathrm{b}}$ & $7.33 \pm 0.46^{\mathrm{a}}$ & $7.01 \pm 0.01^{\mathrm{a}}$ & $7.15 \pm 0.10^{\mathrm{a}}$ & $6.86 \pm 0.15^{\mathrm{a}}$ & $6.87 \pm 0.05^{\mathrm{ab}}$ & $7.35 \pm 0.64^{\mathrm{a}}$ & $7.07 \pm 0.16^{\mathrm{a}}$ & - \\
\hline & COAT-MAP1 & $5.32 \pm 0.03^{\mathrm{a}}$ & $7.01 \pm 0.21^{\mathrm{ab}}$ & $7.00 \pm 0.20^{\mathrm{a}}$ & $7.19 \pm 0.16^{\mathrm{ab}}$ & $6.84 \pm 0.23^{\mathrm{a}}$ & $6.84 \pm 0.26^{\mathrm{a}}$ & $6.78 \pm 0.11^{\mathrm{ab}}$ & $6.98 \pm 0.28^{\mathrm{a}}$ & $7.04 \pm 0.19^{\mathrm{a}}$ & $7.20 \pm 0.44^{\mathrm{a}}$ \\
\hline & COAT-MAP2 & $5.32 \pm 0.03^{\mathrm{a}}$ & $6.98 \pm 0.01^{\mathrm{ab}}$ & $6.90 \pm 0.29^{\mathrm{a}}$ & $7.02 \pm 0.16^{\mathrm{a}}$ & $7.02 \pm 0.00^{\mathrm{a}}$ & $6.76 \pm 0.34^{\mathrm{a}}$ & $6.99 \pm 0.12^{\mathrm{b}}$ & $6.95 \pm 0.08^{\mathrm{a}}$ & $7.05 \pm 0.21^{\mathrm{a}}$ & - \\
\hline & COAT-MAP3 & $5.32 \pm 0.03^{\mathrm{a}}$ & $6.88 \pm 0.11^{\mathrm{ab}}$ & $6.89 \pm 0.45^{\mathrm{a}}$ & $7.39 \pm 0.06^{\mathrm{b}}$ & $6.96 \pm 0.08^{\mathrm{a}}$ & $6.62 \pm 0.40^{\mathrm{a}}$ & $6.99 \pm 0.12^{\mathrm{b}}$ & $7.04 \pm 0.11^{\mathrm{a}}$ & $7.02 \pm 0.23^{\mathrm{a}}$ & $7.46 \pm 0.6$ \\
\hline
\end{tabular}

a-d Data within a column with different superscript letters are significantly different $(P<0.05)$. The statistical analyses were performed comparing means within each microbial group.

${ }_{0}^{1}$ CTRL-air $=$ control in ordinary atmosphere; CTRL-MAP $=$ control in modified atmosphere packaging; COAT-air $=$ coating in ordinary atmosphere; COAT-MAP $=$ coating in modified atmosphere packaging. MAP1 $=75 \% \mathrm{CO}_{2}$ and $25 \% \mathrm{~N}_{2} ; \mathrm{MAP} 2=25 \% \mathrm{CO}_{2}$ and $75 \% \mathrm{~N}_{2} ; \mathrm{MAP} 3=50 \% \mathrm{CO}_{2}$ and $50 \% \mathrm{~N}_{2}$ 
MASTROMATTEO ET AL.

Table 2. Shelf life of low-moisture Mozzarella cheese stored at $4^{\circ} \mathrm{C}^{1}$

\begin{tabular}{|c|c|c|c|c|}
\hline Sample $^{2}$ & $\mathrm{MAL}^{\text {Pseudomonas }}(\mathrm{d})$ & $\operatorname{VMT}(\mathrm{d})$ & $\mathrm{SAL}^{\mathrm{OQ}}(\mathrm{d})$ & Shelf life (d) \\
\hline CTRL-air & $>249$ & $>249$ & $52.52 \pm 3.79^{\mathrm{a}}$ & $52.52 \pm 3.79^{\mathrm{a}}$ \\
\hline CTRL-MAP1 & $>249$ & $>249$ & $57.78 \pm 6.92^{\mathrm{a}}$ & $57.78 \pm 6.92^{\mathrm{a}}$ \\
\hline CTRL-MAP2 & $>249$ & $>249$ & $58.40 \pm 6.06^{\mathrm{a}}$ & $58.40 \pm 6.06^{\mathrm{a}}$ \\
\hline CTRL-MAP3 & $>249$ & $>249$ & $59.62 \pm 5.64^{\mathrm{a}}$ & $59.62 \pm 5.64^{\mathrm{a}}$ \\
\hline COAT-air & $>249$ & $>249$ & $107.85 \pm 9.83^{\mathrm{b}}$ & $107.85 \pm 9.83^{\mathrm{b}}$ \\
\hline COAT-MAP1 & $>249$ & $>249$ & $155.45 \pm 19.06^{\mathrm{c}}$ & $155.45 \pm 19.06^{\mathrm{c}}$ \\
\hline COAT-MAP2 & $>249$ & $>249$ & $102.05 \pm 9.37^{\mathrm{b}}$ & $102.05 \pm 9.37^{\mathrm{b}}$ \\
\hline COAT-MAP3 & $>249$ & $>249$ & $166.36 \pm 38.01^{\mathrm{c}}$ & $166.36 \pm 38.01^{\mathrm{c}}$ \\
\hline
\end{tabular}

Enterobacteriaceae and Pseudomonas spp. were not detected in any samples during the entire storage period. Therefore, for all samples, the $\mathrm{MAL}^{\text {Pseudomonas }}$ value reported in Table 2 was higher than the monitored period. The relatively high microbiological quality of LM Mozzarella cheese used in this study combined with storage at low temperature made it impossible to show the effect of different kinds of packaging on its microbiological quality during storage.

Sensory Analysis. The evolution of overall quality of LM Mozzarella cheese is shown in Figure 1a. The overall quality threshold value is highlighted in figure by the solid horizontal line. All the control samples reached the overall quality threshold value first compared with the coated samples. In particular, all the sensorial attributes such as color, odor, and texture compromised the overall quality of the control samples both in air and MAP (Figure 1b, c, and d), whereas the quality loss for the coated samples was mainly due to the texture. This was probably due to the weight loss that compromises the appearance of the product and, consequently, its acceptability. In fact, firmness was the parameter that affected the acceptability of control samples, whereas the other sensorial attributes such as color, odor, and taste did not influence the overall quality. Coated samples packaged in air and under MAP with low $\mathrm{CO}_{2}$ concentration (MAP2) reached the threshold value before the coated samples under MAP1 and MAP3. In particular, an SAL ${ }^{\mathrm{OQ}}$ value of about $57 \mathrm{~d}$ for all control samples was obtained and no significant difference was observed among them (Table 2). An $\mathrm{SAL}^{\mathrm{OQ}}$ value of about $100 \mathrm{~d}$ was recorded for COAT-air and COAT-MAP2, whereas COAT-MAP1 and COAT-MAP3 samples showed a value of about 160 d. Most probably, edible coatings improved the aesthetic appearance and barrier properties against oxygen and physical stress. Moreover, the use of active compounds loaded with coating combined with MAP reduced physiological changes, oxidation reactions, and microbial growth.

Shelf Life. The LM Mozzarella cheese shelf life is reported in Table 2. On the basis of the recorded results, shelf life of product seemed to be strongly dependent on sensory quality. In fact, no microbiological threshold was reached and no visual molds appeared on the surface to determine product unacceptability. In particular, a shelf-life value of about $57 \mathrm{~d}$ for all control samples was reached. Furthermore, a significant shelf-life prolongation was recorded for samples packaged according to the proposed techniques. Specifically, the combination of active coating and MAP was able to improve the shelf life of LM Mozzarella cheese, reaching a value of about $100 \mathrm{~d}$ for COAT-air and COAT-MAP2 and about $160 \mathrm{~d}$ for COAT-MAP1 and COAT-MAP3 samples.

\section{LM Mozzarella Cheese Stored at $8^{\circ} \mathrm{C}$}

The evolution of TVC, LAB, and lactococci in LM Mozzarella cheese samples did not show differences between samples during the entire storage time (data not shown). In particular, the initial counts for TVC and lactococci were about $7.0 \mathrm{log} \mathrm{cfu} / \mathrm{g}$ and increased until reaching a final value of about $8.0 \log \mathrm{cfu} / \mathrm{g}$. For LAB, the microbial counts ranged from a value of 4.0 to 7.0 $\log \mathrm{cfu} / \mathrm{g}$ at the end of storage.

The evolution of Pseudomonas spp. cell load for LM Mozzarella cheese stored at $8^{\circ} \mathrm{C}$ is shown in Figure 2 . The microbiological analyses for control samples were stopped at $8 \mathrm{~d}$ because of the appearance of the visual molds on the product surface. The COAT-air samples showed a cell load that increased with time and exceeded the threshold value at about $13 \mathrm{~d}$ of storage. The combination of active coating and MAP was able to inhibit the growth of Pseudomonas spp. for the entire storage time. Gram-negative bacteria are gener- 
a)

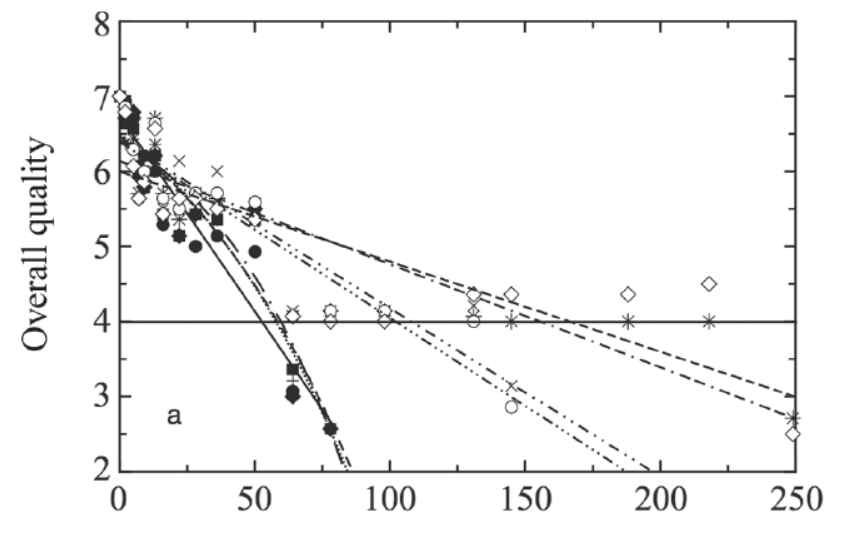

Time (d)

b)

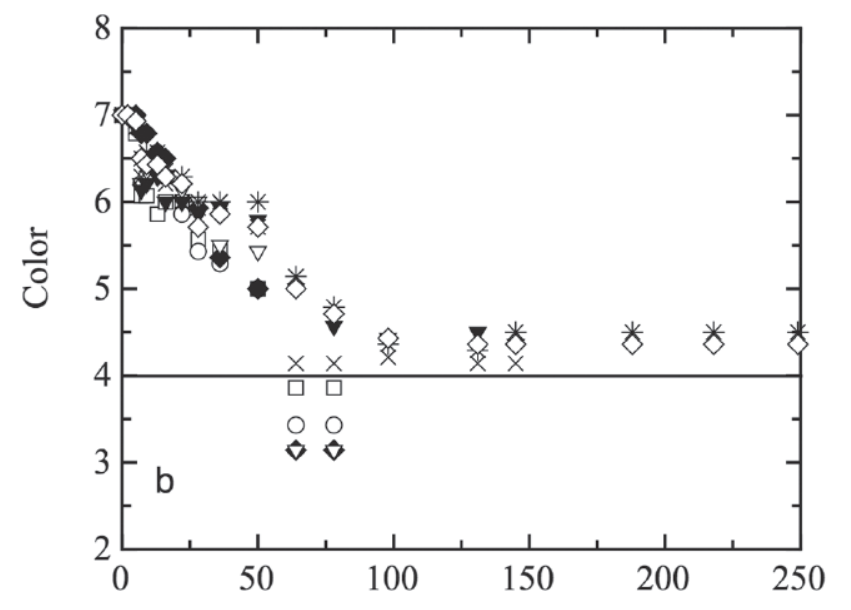

Time (d)

c)

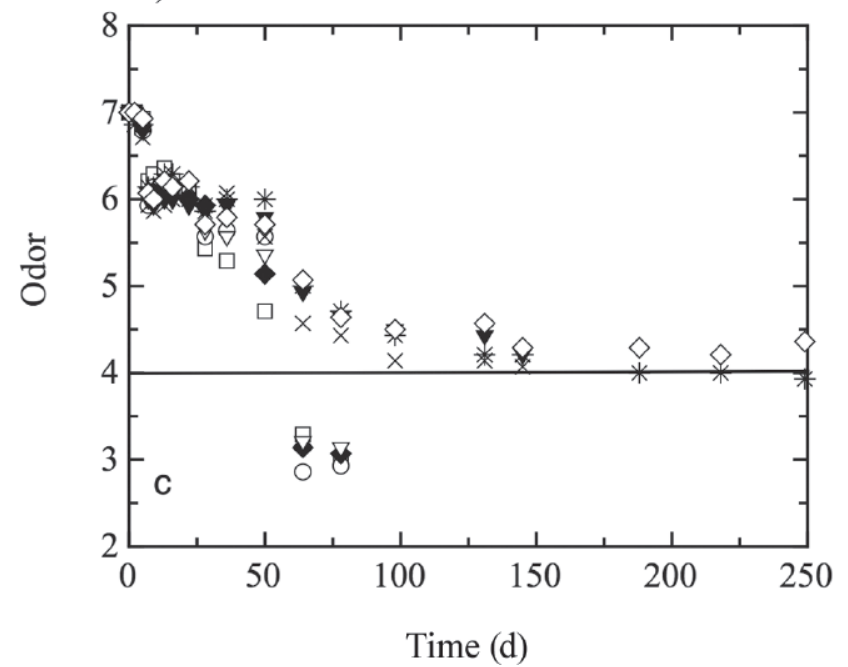

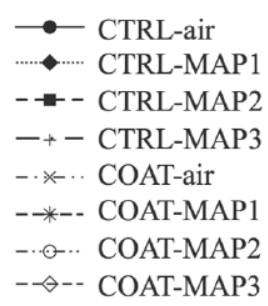

$\square \quad$ CTRL-air

O CTRL-MAP1

- CTRL-MAP2

$\nabla$ CTRL-MAP3

$\times$ COAT-air

* COAT-MAP1

$\checkmark$ COAT-MAP2

$\diamond$ COAT-MAP3 d)

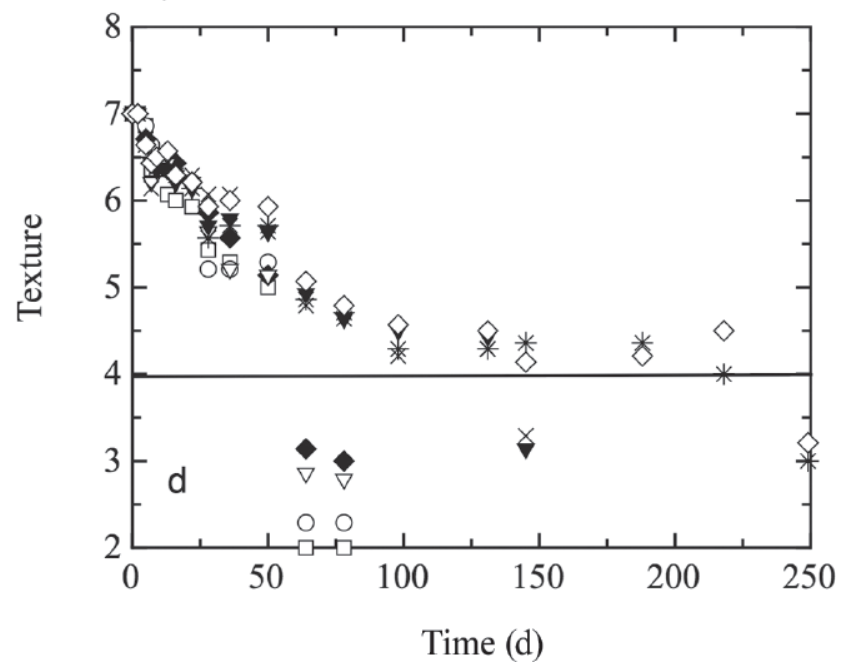

Figure 1. Evolution of overall quality (a), color (b), odor (c), and texture (d) of low-moisture Mozzarella cheese stored at $4^{\circ} \mathrm{C} . \mathrm{CTRL}=$ control; MAP1 = modified atmosphere packaging (MAP) $1\left(75 \% \mathrm{CO}_{2}\right.$ and $\left.25 \% \mathrm{~N}_{2}\right) ; \mathrm{MAP} 2=25 \% \mathrm{CO}_{2}$ and $75 \% \mathrm{~N}_{2} ; \mathrm{MAP} 3=50 \% \mathrm{CO} 2$ and $50 \% \mathrm{~N}_{2} ; \mathrm{COAT}=$ coating treatment; air = ordinary atmosphere. 


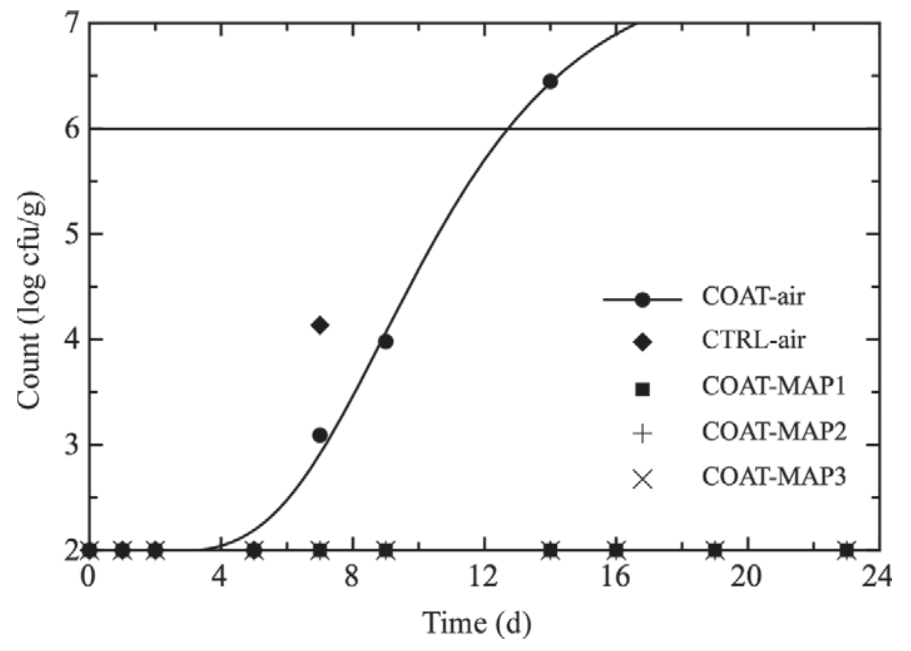

Figure 2. Evolution of Pseudomonas spp. cell load for low-moisture Mozzarella cheese stored at $8^{\circ} \mathrm{C}$. COAT $=$ coating treatment; air $=$ ordinary atmosphere; $\mathrm{CTRL}=$ control; $\mathrm{MAP} 1=$ modified atmosphere packaging (MAP) $1\left(75 \% \mathrm{CO}_{2}\right.$ and $\left.25 \% \mathrm{~N}_{2}\right)$; $\mathrm{MAP} 2=25 \% \mathrm{CO}_{2}$ and $75 \% \mathrm{~N}_{2} ; \mathrm{MAP} 3=50 \% \mathrm{CO}_{2}$ and $50 \% \mathrm{~N}_{2}$.

ally more sensitive to $\mathrm{CO}_{2}$ than the gram-positive ones (Rosenthal et al., 1991). The results confirm data from the literature on the effect of active coating in combination of MAP on the spoilage microorganisms of dairy product (Conte et al., 2009; Del Nobile et al., 2009). Enterobacteriaceae were not detected in any samples during the entire storage period.

From the overall quality point of view, CTRL-air and COAT-air samples did not reach the SAL for the period

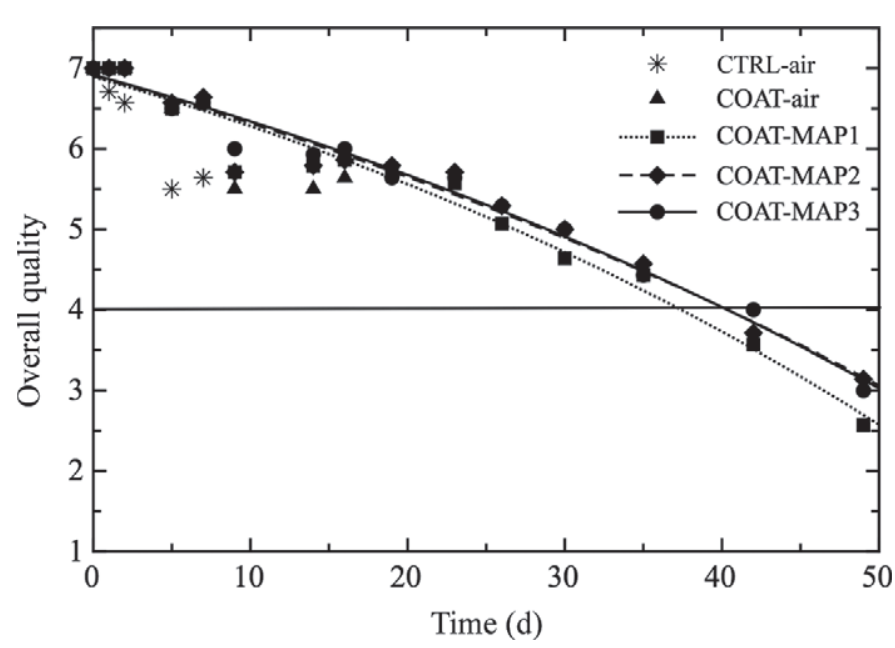

Figure 3. Evolution of overall quality of low-moisture Mozzarella cheese stored at $8^{\circ} \mathrm{C}$. CTRL $=$ control; air $=$ ordinary atmosphere; COAT $=$ coating treatment; MAP1 $=$ modified atmosphere packaging (MAP) $1\left(75 \% \mathrm{CO}_{2}\right.$ and $\left.25 \% \mathrm{~N}_{2}\right) ; \mathrm{MAP} 2=25 \% \mathrm{CO}_{2}$ and $75 \% \mathrm{~N}_{2}$; $\mathrm{MAP} 3=50 \% \mathrm{CO}_{2}$ and $50 \% \mathrm{~N}_{2}$. in which they were monitored (Figure 3). As mentioned before, the analyses for these samples were stopped because the microbiological threshold limit was reached. The adopted packaging strategy allowed prolonging the overall quality of the LM Mozzarella cheese. In particular, the samples packaged under high $\mathrm{CO}_{2}$ concentration (COAT-MAP1) reached the overall quality threshold value first, followed by the samples under low $\mathrm{CO}_{2}$ levels (COAT-MAP2 and COAT-MAP3).

The MAL ${ }^{\text {Pseudomonas }}$, $\mathrm{SAL}^{\mathrm{OQ}}$, and shelf-life values for LM Mozzarella cheese stored at $8^{\circ} \mathrm{C}$ are reported in Table 3. The data highlight that the limiting factor for the shelf life of CTRL-air was the appearance of visual molds on the surface. For these samples, a shelf-life value of about $8.0 \mathrm{~d}$ was obtained. The microbiological quality was the factor that limited the shelf life of samples subjected at coating treatment under air, with a value of about $13 \mathrm{~d}$. Active coating treatment in combination with MAP was able to improve the product shelf life until obtaining a value of about $37 \mathrm{~d}$ for COAT-MAP1 and $40 \mathrm{~d}$ for COAT-MAP2 and COATMAP3 samples. In this case, the sensory quality was the parameter that compromised the product shelf life, whereas the Pseudomonas spp. growth and the molds did not represent a limiting factor. Therefore, the use of MAP highlighted the higher inhibitory effect on the growth of molds, as stated by Michniewicz (1998). Data confirm the effect of potassium sorbate incorporated into edible coatings as an antimicrobial agent against microbial spoilage and molds such as Penicillium spp. and Aspergillus spp. (Mehyar et al., 2011; Sayanjali et al., 2011).

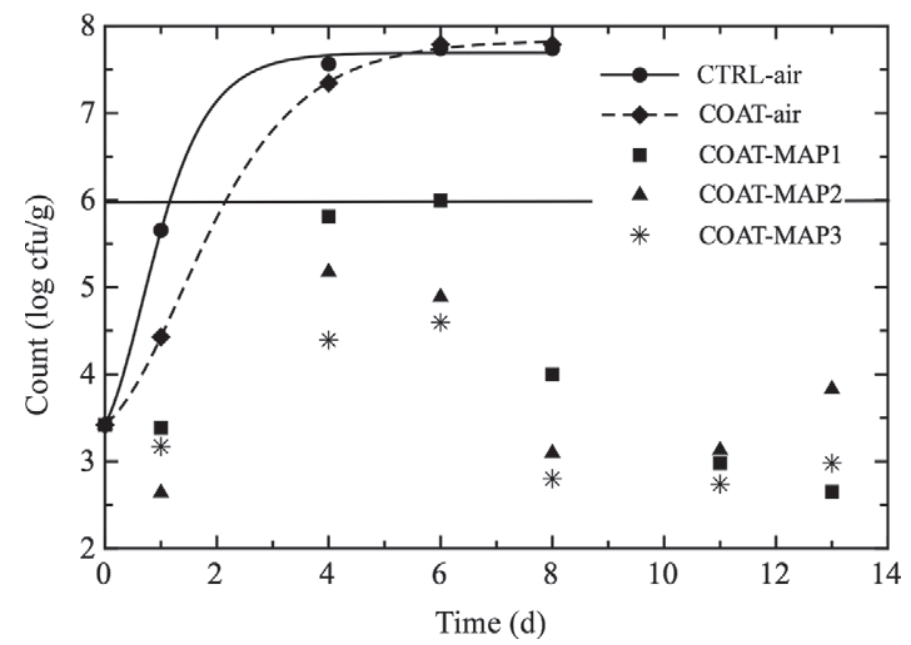

Figure 4. Evolution of Pseudomonas spp. cell load for low-moisture Mozzarella cheese stored at $14^{\circ} \mathrm{C} . \mathrm{CTRL}=$ control; air $=$ ordinary atmosphere; COAT $=$ coating treatment; $\mathrm{MAP} 1=$ modified atmosphere packaging (MAP) $1\left(75 \% \mathrm{CO}_{2}\right.$ and $\left.25 \% \mathrm{~N}_{2}\right)$; MAP2 $=25 \% \mathrm{CO}_{2}$ and $75 \% \mathrm{~N}_{2} ; \mathrm{MAP} 3=50 \% \mathrm{CO}_{2}$ and $50 \% \mathrm{~N}_{2}$. 
Table 3. Shelf life of low-moisture Mozzarella cheese stored at $8^{\circ} \mathrm{C}^{1}$

\begin{tabular}{lcccr}
\hline Sample $^{2}$ & MAL $^{\text {Pseudomonas }}(\mathrm{d})$ & $\mathrm{VMT}(\mathrm{d})$ & SAL $^{\mathrm{OQ}}(\mathrm{d})$ & \multicolumn{1}{c}{ Shelf life $(\mathrm{d})$} \\
\hline CTRL-air & $>7$ & $8.00 \pm 0.00$ & $>7$ & $8.00 \pm 0.00^{\mathrm{a}}$ \\
COAT-air & $12.72 \pm 0.40$ & $>14$ & $>14$ & $12.72 \pm 0.40^{\mathrm{b}}$ \\
COAT-MAP1 & $>49$ & $>49$ & $37.38 \pm 1.48^{\mathrm{a}}$ & $37.38 \pm 1.48^{\mathrm{c}}$ \\
COAT-MAP2 & $>49$ & $>49$ & $40.35 \pm 1.71^{\mathrm{a}}$ & $40.35 \pm 1.71^{\mathrm{d}}$ \\
COAT-MAP3 & $>49$ & $>49$ & $40.33 \pm 1.18^{\mathrm{a}}$ & $40.33 \pm 1.18^{\mathrm{d}}$ \\
\hline
\end{tabular}

${ }^{\mathrm{a}-\mathrm{d}}$ Data within a column with different superscript letters are significantly different $(P<0.05)$.

${ }^{1} \mathrm{MAL}=$ microbiological acceptability limit; $\mathrm{VMT}=$ visual molds time; $\mathrm{SAL}^{\mathrm{OQ}}=$ sensorial acceptability limit in terms of overall quality.

${ }^{2} \mathrm{CTRL}$-air $=$ control in ordinary atmosphere; COAT-air = coating in ordinary atmosphere; COAT-MAP = coating in modified atmosphere packaging. $\mathrm{MAP} 1=75 \% \mathrm{CO}_{2}$ and $25 \% \mathrm{~N}_{2} ; \mathrm{MAP} 2=25 \% \mathrm{CO}_{2}$ and $75 \% \mathrm{~N}_{2}$; $\mathrm{MAP} 3=50 \% \mathrm{CO}_{2}$ and $50 \% \mathrm{~N}_{2}$.

\section{LM Mozzarella Cheese Stored at $14^{\circ} \mathrm{C}$}

The evolution of TVC, LAB, and lactococci in LM Mozzarella cheese samples did not show differences among samples during the entire storage time (data not shown). In particular, the initial cell load for TVC and LAB was about $5.0 \mathrm{log} \mathrm{cfu} / \mathrm{g}$ and increased until reaching a final value of about $8.0 \mathrm{log} \mathrm{cfu} / \mathrm{g}$. For lactococci, the microbial counts ranged from a value of 7.0 to 8.0 $\log \mathrm{cfu} / \mathrm{g}$ at the end of storage.

Figure 4 shows the evolution of Pseudomonas spp. cell load for the LM Mozzarella cheese stored at $14^{\circ} \mathrm{C}$. Temperature was the most important variable for the microbiological quality of the product. This is highlighted by the faster increase in spoilage microorganisms cell load compared with that of the samples stored at lower temperature. Specifically, CTRL-air samples reached the microbiological threshold value first, followed by the COAT-air samples. Coated samples under modified atmosphere conditions did not exceed the limit value during the entire storage period. In particular, the cell load increased during the first $4 \mathrm{~d}$ and then a decrease was observed. The MAL for all samples are reported in Table 4 . The MAL ${ }^{\text {Pseudomonas }}$ value was about 1.0 and $2.0 \mathrm{~d}$ for control and active coating samples, respectively. The adopted strategy in this study was able to improve the microbiological quality of product stored under thermal abuse. The MAL ${ }^{\text {Pseudomonas }}$ value for coated samples packaged in MAP was higher than the monitored period. Moreover, the inhibitory effect on the growth of molds was also observed. Enterobacteriaceae were not detected in any samples during the entire storage period.

From a sensory point of view, the combination of active coating and MAP was able to improve the quality of product (Figure 5). In fact, CTRL-air and COAT-air rapidly reached the threshold value with respect to the COAT-MAP samples. In particular, an $\mathrm{SAL}^{\mathrm{OQ}}$ value of about 2.32 and $4.00 \mathrm{~d}$ was observed for CTRL-air and COAT-air, respectively (Table 4). On the other hand, coated samples packaged under MAP showed an $\mathrm{SAL}^{\mathrm{OQ}}$ value of about $11 \mathrm{~d}$. Moreover, no significant differences between different MAP was observed.

The shelf life for LM Mozzarella cheese stored at $14^{\circ} \mathrm{C}$ is reported in Table 4 . The microbiological quality was the factor limiting the shelf life of control and active coating samples packaged in air. For these samples, a shelf-life value of about 1.0 and $2.0 \mathrm{~d}$, respectively, was observed, whereas a shelf life of $11 \mathrm{~d}$ for coated samples was reached. With regard to the VMT parameter, no visual molds appeared during the storage time for all samples. The data confirmed the antimicrobial

Table 4. Shelf life of low-moisture Mozzarella cheese stored at $14^{\circ} \mathrm{C}^{1}$

\begin{tabular}{lcccr}
\hline Sample $^{2}$ & MAL $^{\text {Pseudomonas }}(\mathrm{d})$ & VMT $(\mathrm{d})$ & SAL $^{\mathrm{OQ}}(\mathrm{d})$ & \multicolumn{1}{c}{ Shelf life $(\mathrm{d})$} \\
\hline CTRL-air & $1.16 \pm 0.04^{\mathrm{a}}$ & $>8$ & $2.32 \pm 0.01^{\mathrm{a}}$ & $1.16 \pm 0.04^{\mathrm{a}}$ \\
COAT-air & $2.16 \pm 0.07^{\mathrm{b}}$ & $>8$ & $4.02 \pm 0.86^{\mathrm{b}}$ & $2.16 \pm 0.07^{\mathrm{a}}$ \\
COAT-MAP1 & $>13$ & $>13$ & $10.93 \pm 0.50^{\mathrm{c}}$ & $10.93 \pm 0.50^{\mathrm{b}}$ \\
COAT-MAP2 & $>13$ & $>13$ & $11.04 \pm 1.36^{\mathrm{c}}$ & $11.04 \pm 1.36^{\mathrm{b}}$ \\
COAT-MAP3 & $>13$ & $>13$ & $11.53 \pm 0.70^{\mathrm{c}}$ & $11.53 \pm 0.70^{\mathrm{b}}$ \\
\hline
\end{tabular}

${ }^{\mathrm{a}-\mathrm{C}}$ Data within a column with different superscript letters are significantly different $(P<0.05)$.

${ }^{2} \mathrm{MAL}=$ microbiological acceptability limit; $\mathrm{VMT}=$ visual molds time; $\mathrm{SAL}^{\mathrm{OQ}}=$ sensorial acceptability limit in terms of overall quality.

${ }^{2} \mathrm{CTRL}$-air $=$ control in ordinary atmosphere; COAT-air = coating in ordinary atmosphere; COAT-MAP = coating in modified atmosphere packaging. MAP1 $=75 \% \mathrm{CO}_{2}$ and $25 \% \mathrm{~N}_{2} ; \mathrm{MAP} 2=25 \% \mathrm{CO}_{2}$ and $75 \% \mathrm{~N}_{2}$; $\mathrm{MAP} 3=50 \% \mathrm{CO}_{2}$ and $50 \% \mathrm{~N}_{2}$. 


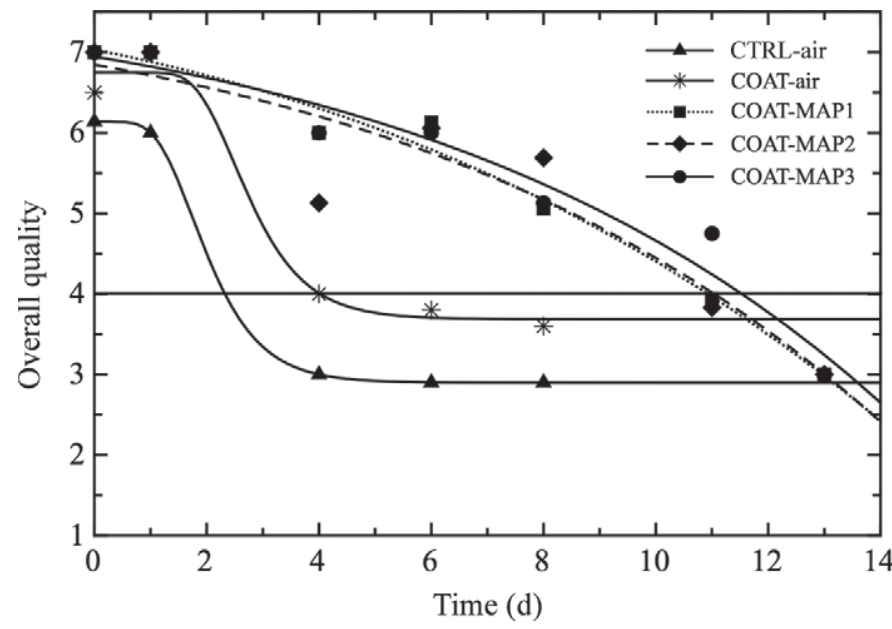

Figure 5. Evolution of overall quality of low-moisture Mozzarella cheese stored at $14^{\circ} \mathrm{C}$. CTRL = control; air = ordinary atmosphere; COAT $=$ coating treatment MAP1 $=$ modified atmosphere packaging (MAP) $1\left(75 \% \mathrm{CO}_{2}\right.$ and $\left.25 \% \mathrm{~N}_{2}\right) ; \mathrm{MAP} 2=25 \% \mathrm{CO}_{2}$ and $75 \% \mathrm{~N}_{2}$; $\mathrm{MAP} 3=50 \% \mathrm{CO}_{2}$ and $50 \% \mathrm{~N}_{2}$.

and antifungal effect of potassium sorbate and MAP on improving the microbiological quality and safety of the product under thermal abuse conditions.

\section{CONCLUSIONS}

The active coating combined with packaging in modified atmosphere were used to prolong the shelf life of LM Mozzarella cheese. Microbial and sensorial properties were monitored to determine the quality loss during storage at 4,8 , and $14^{\circ} \mathrm{C}$. Results highlighted that the approach used in this study was effectively able to prolong the shelf life of the product by inhibiting the spoilage microorganisms and molds. The sensory quality was also improved due the ability of coating to prevent excessive dehydration from the product surface. Moreover, it should be emphasized the importance of this strategy under thermal abuse conditions, as it is able to enhance the safety of the product. Therefore, the combination of active coating and MAP represents a strategic solution to prolong the shelf life of LM Mozzarella cheese. In addition, edible coatings guarantee a considerably lower packaging weight, enhance product appearance, and ensure its safety. Moreover, the simplicity and relative economy could be very beneficial and of commercial importance to the dairy industry.

\section{ACKNOWLEDGMENTS}

This work was financially supported by Ministero dell'Economia e delle Finanze, Ministero dell'Istruzione, dell'Università e della Ricerca Scientifica e Tecnologica e l'Assessorato Bilancio e Programmazione Regione
Puglia by the programme Art. 13 - DD prot. 713/Ric. 29 October 2010 ["Innovative packaging solutions to extend shelf life of food products (INFOPACK)"].

\section{REFERENCES}

Alves, R. M. V., C. I. G. De Luca Sarantópoulos, A. G. Fernandes Van Dender, and J. De Assis Fonseca Faria. 1996. Stability of sliced Mozzarella cheese in modified atmosphere packaging. J. Food Prot. 59:838-844.

Brody, A. L. 2001. Say "cheese"-And package it, please! Food Technol. 55:76-77.

Cagri, A., Z. Ustunol, and E. T. Ryser. 2004. Antimicrobial edible films and coating. J. Food Prot. 67:833-848.

Conte, A., D. Gammariello, S. Di Giulio, M. Attanasio, and M. A. Del Nobile. 2009. Active coating and modified-atmosphere packaging to extend the shelf life of Fior di Latte cheese. J. Dairy Sci. 92:887-894.

Corradini, C., and N. Innocente. 2002. Parametri chemiometrici e descrittori sensoriali del Montasio DOP. Notiziario ERSA 4:43-45.

Del Nobile, M. A., D. Gammariello, A. Conte, and M. Attanasio. 2009. A combination of chitosan, coating and modified atmosphere packaging for prolonging Fior di Latte cheese shelf life. Carbohydr. Polym. 78:151-156.

Eliot, S. C., J.-C. Vuillemard, and J.-P. Emond. 1998. Stability of shredded Mozzarella cheese under modified atmospheres. J. Food Sci. $63: 1075-1080$.

Farkye, N. Y., L. J. Kiely, R. D. Allshouse, and P. S. Kindstedt. 1991. Proteolysis in Mozzarella cheese during refrigerated storage. J. Dairy Sci. 74:1433-1438.

Floros, J. D., P. V. Nielsen, and J. K. Farkas. 2000. Advances in modified atmosphere and active packaging with applications in the dairy industry. Packaging of milk products. Bull. Int. Dairy Fed. 346:22-28.

Gammariello, D., S. Di Giulio, A. Conte, and M. A. Del Nobile. 2008. Effects of natural compounds on microbial safety and sensory quality of Fior di Latte cheese, a typical Italian cheese. J. Dairy Sci. 91:4138-4146.

Guilbert, S. 1986. Technology and application of edible protective films. Pages 371-394 in Food packaging and preservation. M. Mathlouthi, ed. Elsevier Applied Science, New York, NY.

ISO (International Organization for Standardization). 1993. Sensory analysis - General guidance for the selection, training and monitoring of assessors-Part 1: Selected assessors. ISO 8586-1993. ISO, Geneva, Switzerland.

ISO (International Organization for Standardization). 2001. Milk and milk products - General guidance for the preparation of test samples, initial suspensions and decimal dilutions for microbiological examination. ISO 8261:2001. ISO, Geneva, Switzerland.

Kindstedt, P. S. 1993. Effect of manufacturing factors, composition, and proteolysis on the functional characteristics of Mozzarella cheese. Crit. Rev. Food Sci. Nutr. 33:167-187.

Mehyar, G. F., H. M. Al-Qadiri, H. A. Abu-Blan, and B. G. Swanson. 2011. Antifungal effectiveness of potassium sorbate incorporated in edible coatings against spoilage molds of apples, cucumbers, and tomatoes during refrigerated storage. J. Food Sci. 76:M210M217.

Michniewicz, J. 1998. Food packaging with modified atmosphere. Chłodnictwo 33:42-44. (In Polish.)

Molska, I. 1988. Zarys Mikrobiologii Mleczarskiej. Page 174. Państwowe Wydawnictwo Rolnicze i Leśne (PWRiL), Warsaw, Poland.

Pantaleão, I., M. M. E. Pintado, and M. F. F. Poças. 2007. Evaluation of two packaging systems for regional cheese. Food Chem. 102:481-487.

Papaioannou, G., I. Chouliara, A. E. Karatapanis, M. G. Kontominas, and I. N. Savvaidis. 2007. Shelf-life of a Greek whey cheese under modified atmosphere packaging. Int. Dairy J. 17:358-364.

Pranoto, Y., V. M. Salokhe, and S. K. Rakshit. 2005. Physical and antibacterial properties of alginate-based edible film incorporated with garlic oil. Food Res. Int. 38:267-272. 
Rosenthal, I., B. Rosen, S. Bernstein, and G. Popel. 1991. Preservation of fresh cheeses in a $\mathrm{CO}_{2}$-enriched atmosphere. Milchwissenschaft 46:706-708.

Sayanjali, S., B. Ghanbarzadeh, and S. Ghiassifar. 2011. Evaluation of antimicrobial and physical properties of edible film based on carboxymethyl cellulose containing potassium sorbate on some myco- toxigenic Aspergillus species in fresh pistachios. Lebensm. Wiss. Technol. 44:1133-1138.

US FDA (United States Food and Drug Administration). 1989. Code of Federal Regulations, Title 21, Food and Drugs: Parts 100-169. US Dept. Health Human Services, Washington, DC. 